\title{
Issues \& Options of Sustainable Livelihoods and Biodiversity Conservation of High Altitude Community Forests of Pyuthan District
}

\author{
R.B. Thakur ${ }^{1}$, Nahakul K.C. ${ }^{2}$, Ramu Subedi ${ }^{3}$, \\ Peter Brahmmney ${ }^{4}$ N.P. Yadav, Ph.D. ${ }^{5}$ \\ \& Nirmala Kr. Phulara6
}

\begin{abstract}
Community Forest is one of the most successful forestry programs; however, it has several anomalies pertaining to the high altitude community forests. Construction of Goth (small hut), cultivation of crops, wildlife hunting, heavy grazing and lopping and haphazard NTFP collection are the major issues of high altitude community forests whereas it possesses a large range of pasture land which provides livestock for grazing as well as valuable NTFPs for collectors. It is also a reservoir of important and commercially viable biological diversity which has a great potential for bio-prospecting.
\end{abstract}

Key Words: Livelihoods, NTFPs, Wildlife conflict, Land tenure, Pasture land, Epidemic disease, Wetlands, Bio-prospecting, Indigenous knowledge \& Skill technology (IKST)

\section{Introduction}

\section{Status of community forests}

Of all the programs of Nepal's forestry sector, community forestry has been accorded the highest priority. Essentially, it is a participatory approach that has evolved over the last 25 years. Nepal's community forestry has been widely acclaimed as a successful forest management approach. To date, 1.1 million hectares of forest (about $25 \%$ of the national forest area) has been handed over to more than 13,000 community forest user groups involving 1.4 million households ( $35 \%$ of Nepal's total population).

\section{Community forests in mid-hills versus high-hills}

High altitude community forests generally denote the community forests which have altitudinal range more than $2000 \mathrm{~m}$. The high altitude areas differ greatly from the mid-hills in biophysical and natural aspects, socio-economic and demographic aspects, and institutional aspects. The forests in high altitude areas are extensive in area and are contiguous at great distances, but under heavy pressure near habitations. The villages around these forests are

\footnotetext{
High Altitude Forest Management Expert, LFP, Kathmandu, rbthakur@gmail.com

2 Mid-west Programme Co-ordinator; LFP, Mid-west Programme Co-ordinator office, Dang, Ghorahi n-kc@lfpmw.org.np

Hills Forestry Advisor, LFP, Programme Coordination Office, Baluwatar, Kathmandu, r-subedi@lfp.org.np

4 LFP, Programme Coordination Office, Baluwatar, Kathmandu, p_branney@lfp.org.np

Technical Forest Advisor, Mid-West Co-ordination Office, Dang,n-yadav@lfpmw.org.np

6 Technical Supervisor, LFP, Salyan, econirmala@yahoo.com
} 
very small, often composed of only a few households spread over a distance of several kilometers. Sepe Charpate community forest user group of Rukum district has only 150 households but they occupy more than 2500 ha. of forests. All these characteristics make the forests of high altitude areas very different from the mid-hills. Community forest of high altitude is passively managed without people's active involvement.

\section{Methodology}

\section{Site selection}

Syaulibang, Rajabara, Arkha VDCs \& some part of Khung VDC of Pyuthan district were selected for the study sites because their altitude ranges above $2000 \mathrm{~m}$. This high altitude forest possesses high valuable $\&$ commercially exploitable forest resources which are not properly utilized and destroyed in the production site.

\section{Data collection, analysis \& interpretation}

Both primary and secondary data was collected. Primary data was collected from the study sites while secondary data was collected from published and unpublished documents regarding this research. Primary Data Collection was carried out through key informants' survey, household survey with questionnaires, participatory resource mapping, direct observation, group discussion etc. Secondary data was collected from various published and unpublished documents related to this study. They were maps, official records, research reports, forest mgt. Plan, annual reports and other published and unpublished materials from Department of Forests (DOF), Institute of Forestry (IOF), Department of Forestry Research \& Survey Centre (DFRSC), Livelihoods \& Forestry Programme (LFP), Department of Plant Resource (DPR), International Center for Integrated Mountain Development (ICIMOD), IUCN Nepal, WWF Nepal, NTNC Nepal etc. Data analysis were carried through different qualitative and quantitative methods and interpretation of these data were carried out through interviewer's quoted form, case study etc.

\section{Results \& Discussion}

Community forestry is one of the most successful approaches of the forestry sector, is defined as a process through which government transfers the responsibility of managing forests to the communities and recognizes latter's right to use on sustainable basis.

\section{Issues related to livelihoods of high altitude CFUG}

\section{- Relation of livelihoods with agriculture crops}

Traditional farming system in high altitude region is primarily based on agriculture, forestry and livestock. Agricultural farming is generally practiced in lowland called as Bensi and Goth (small hut) is prepared in high lands locally known as Bunki. According to agroclimatic classification, high altitude region of Pyuthan district such as Syaulibang, Rajabara and Arkha VDCs lie in cool temperate monsoon where two crops except paddy are grown in lowland and only one crop except paddy are grown in high lands. Maize and potato are 
commonly grown during the summer and rainy season while wheat is commonly grown in winter and summer season. Due to extreme environmental severity, the transhumance grazing system may get evolved. Due to lack of enough land for grazing in Bensi and availability of enough forage in Bunki, herders of high altitude take their livestock in Bunki in rainy season. After harvesting the rainy agricultural crops such as maize, potato etc., livestock are taken in Bensi when fields have no crops and also the arrival of extreme cold winter season, and snowfall in the Bunki. Kamala Budha of Syaulibang VDC-5, Banstalla, Pyuthan says that Agricultural by-products and straw are harvested before the arrival of winter season, and these are fed during the winter season when the entire village is covered with snow, and Water is provided to the livestock by melting the ice and snow. Keeping the livestock in Goth, herders involve in cultivating potato, cutting / lopping the fodder from the forest; and often in grazing livestock which results in severe reduction of forest regeneration and continuous decline of the forest status. Only the over-matured, dead, dying and diseased trees remain in forest.

\section{- Relation of livelihoods with livestock}

Rural people living in Goth have a very difficult daily life. Their Goth is a temporary structure roofed with straw, and having water leakage from the roof during rainy season. Besides, herders have to bring water from a distant. Sometimes, it may take a few hours. The herders may not have contact with their families for a few weeks or even months. They lack sufficient food grains, and they have to depend on forests for their vegetables. Large no. of women also lives in Goth, and this might be due to the higher no. of migration of youth for employment in foreign country.

\section{- Relation of livelihoods with non-timber forest products (NTFPs)}

High altitude community forests also possess a great amount of valuable and commercially useful NTFPs (Non Timber Forest Products), commonly known as medicinal plants . Some less bulky and commercially high valuable NTFPs are haphazardly collected and sold in a nearby village markets, however, local people do not get a reasonable price. Other commercially viable but bulky NTFPs have not been utilized. For instance, Lokta (Daphne bholua) bark can be utilized for the local hand-made paper production but they have not yet utilized it as a potential resource for the promotion of livelihood. However, NTFP resources continue to be integral parts of livelihoods since wild fruits, vegetables, medicines etc. are the principal derivatives collected from the forests.

Mr. Rum Bahadur Malla of Syaulibang VDC-2, Pyuthan says that people depend on forests for meeting their needs of vegetable such as Sisnu, Niuro, Bako, Halhale, Khenoure, different varieties of mushrooms, new sprouting of Nigalo, garlic etc. He again adds that most of the wild vegetables are declining except Sisnu. Similarly, people depend on medicinal plants for curing different health problems. Medicinal plants such as Tite (Chiraito), Satuwa, Raktmula, Pakhanved, Sutkegola, resin of Kharsu, Silajeet, Panchaule, Bhutkesh, Padamchalno, Bikh, Siltimur, Samayo (Sugandhawal) etc. are widely collected for both domestic as well as commercial purposes .Wild fruits such as Chutro, Kaphal, Aiselu, Guela, Ghumelu, Date 
Okhar etc. are also collected from the forest. Local people also prepare insecticidal mixtures from the wild plants such as mixture of leaf extract of Sisnu and Titepati, crushed fruit of Timur etc. are sprayed in crops for the protection of diseases and pests. Malla again adds that there is lack of veterinary services in his village and extracts of wild plants such as Lasun, Ketuki etc. are used as ethnoveterinary drugs . There is a large scope of managing NTFPs from this region, but only few initiatives have been undertaken to utilize the resource for poverty reduction.

\section{- Losses of agricultural products by rodents, porcupine and wild boar}

There is a large amount of manure production by keeping the livestocks in the Goth. It is utilized in the farm around the Goth for the production of potato. Most of the herders do not want to cultivate the potato farming since wild animals such as rodents, porcupine and wild boar destroy the crops.

\section{- Introduction of the improved exotic livestock varieties}

Development endeavor may suggest for farming of improved livestock, but it is not possible without stall feeding. There may be some risk as there are vast no. of poisonous plants in the forests and exotic livestock can not identify either of the poisonous plants. To graze the exotic livestocks in the forest is out of thought. These improved livestocks can not survive for long period. Mr. Man Bahadur Pun of Rajabara VDC-6, Dhwaktir, Pyuthan says "I had brought cattles from the Puja VDC, nearby village which lies in low altitude/ mid-hills and took them in the forest for grazing, but they died within a few hour by eating poisonous plants". Thus, existing farming system of high altitude people should not be altered, since it may break a chain of linkages with livelihoods and overall farming systems of high mountain region.

\section{Issues related to biodiversity conservation in high altitude CFUG}

\section{- Wildlife hunting}

Wildlife hunting is one of the major threats to the livestock while being kept in Goth. Gobardhan Thapa, secretary of Suke Tersedhara CFUG, Rajabara VDC says that Most of the herders make the killed livestock poisonous to kill the wildlife predator. He again says that once there were plenty of wildlife such as fox, leopard, bear etc. But due to such practice of killing the wildlife, they are not commonly seen these days. Moreover, wildlife poachers are frequently seen in the forest and most of the herders have kept gun in their huts. Wildlife hunting is a fashion for the people and no organizations have yet controlled it, and people are not aware about the legal provisions against wildlife hunting. Gore Pun and Bom Bahadur Malla, Syaulibang VDC-2, Choutara say that they have been killing Ratuwa deer from 6-7 years and might have killed more than dozens of Ratuwa deer till to date. They claim that it is a fashion of a prosperous family member in the society. They tell that they do not know about legal provisions and no one has yet been punished for the wildlife hunting. On this issue, Mr. Raj Dev Yadav, DFO, Pyuthan says "Due to inaccessibility and past political conflict, there was low movement of government staffs in those areas, but now we will take action against it. Community forests of high altitude have not taken any action against controlling the wildlife 
hunting. Most of the committee members of CFUG keep local gun (Bharuwa Banduk) in Goth themselves like Lil Bahadur B.M., secretary of Lohori CFUG.

\section{- Livestock and wildlife conflict}

Mr. Ram Bahadur Pun of Arkha VDC-1, Lujibang, Pyuthan says that there has aroused a large conflict between wildlife and domestic animals for keeping the livestock in the forests as the latter disturbs the habitat of the former as well as it facilitates the wildlife hunting. Once wildlife killed a large no. of livestocks even herders left them a few hours. But now wildlife is rarely seen. However, wolves are a problem for herders as they can kill more than 15 livestocks within a few hours if the livestocks do not follow.

\section{- Livestock and regeneration status of forests}

Herders of Arkha VDC, Pyuthan Mr. Moti Pun, Mr. Jang Bahadur Budha and Purna Bahadur Gharti say that the regeneration status of the forest is much sparse. It is due to the fact that there are large no. of Goth in the forests. Mr. Gobardhan Thapa, secretary of Suke Terse Dhara CFUG of Rajabara VDC, Pyuthan says there are more than 30 Goth only in the community forest. On an average, local people keep 6 cows, 4 buffaloes, 3 sheep, 8 goat and 2 dogs, and total 23 livestocks by each family. Thus, there would be 180 cows, 120 buffaloes, 90 sheep, 240 goats and 60 dogs, total 690 livestocks only within Suke Tersedhara community forest. These huge amount of livestocks destroy the regeneration by trampling as well as eating the new sprouts.

\section{- Pressure of NTFP collectors in pasture land}

Due to high grazing intensity in alpine pasture land, commonly known as Kharka, commercially valuable NTFPs are over-exploited due to trampling by the livestock as well as pre-mature and heavy collection by the herders as well as the low resillence capacity of the NTFPs against externalities. Once these NTFPs were abundant, but now-a-days they are sparse and rarely seen. Herders and local people collect these NTFPs in a haphazard and unsystematic manner, so NTFPs can not support the livelihoods of rural people in a sustainable way. Community forests have not taken revenue from the NTFP collectors and local village traders, so they have not contributed in community forests as well as community development works.

\section{- Heavy livestock pressure in the pasture land}

There is a huge livestock pressure in the alpine pasture land since livestock holding per household is larger in the high altitude than mid-hills and Terai. Similarly, regenerative capacity of alpine pasture is also low. According to Lil Bdr. B.M., secretary of Jadibuti Focal Point and member of Kothivir community forest users group, Syaulibang VDC-5, Khorabang says that due to beyond the carrying capacity of the pasture land, most of the commercial and valuable NTFPs such as Panch aule, Bikh, Raktmula, Jatamasi, Bhutkesh etc. were once abundant, but now they are rarely seen. Moreover, pasture land is degraded due to heavy grazing that result in soil erosion and landslide. 


\section{- Bursting epidemic diseases to the livestock}

Herders are mostly affected by bursting epidemic diseases such as diarrhoeal disease (Chheruwa), foot and mouth rust disease (Khoret), nymph infestation (Namle keera), Patke disease, Charchare disease etc.occuring to the livestock. High altitude dwellers are far from the modern veterinary services, they have to depend on only ethno-veterinary services from the local vaidya/ healers. Gobardhan Thapa, secretary of Surke Tersedhara CFUG, Rajabara VDC-5 says "I have lost 30 livestocks in the last year from the epidemic disease locally called as Patake disease".

\section{- Utilization of over-matured, dead, dying and diseased trees}

High altitude community forests have a large amount of over-matured, diseased, felled and decayed trees, but they are not utilized. Lack of proper transportation system is one of the major hindrances for the utilization of timber. Bam Bahadur Budhathoki of Rajabara VDC-6, Pyuthan says sadly that timber is decaying without utilizing in one part of the country while timber import from the foreign country is increasing every day.

\section{- Siltation of wetlands}

Although wetlands are lower in the high altitude, they are facing the problem of siltation that results in lowering the depth of water. Dakhada lake which is nearly 5 meter in depth and area more than 3 ropani, lies at 2444 meter altitude in Syaulibang VDC, is now heavy silted that results in declining the wetland fauna and flora. Mr. Tul Bahadur Sen, secretary of Tinpure community forests, Syaulibang VDC-1, Choutara says that once there used to be large flocks of ducks coming during the month of Asoj and Kartik, but now they are rarely seen in the lake.

\section{- Land tenure issues}

Land tenure issue is one of the serious issues of the high altitude community forests. According to the existing laws and regulation, agricultural farming such as potato farming etc. and construction of Goth in the natural forest including community forests are illegal activities. However, traditional mountain farming system does not sustain without keeping the livestock in Goth in summer and rainy season since there is not enough space in lowland Bensi for keeping the animals. Considering these facts, current legislation should be amended to make the Goth and farming in the forest with no extending the existing area of land. Do the local people have tenure rights on the land where they are adopting traditional farming practices is still a question?

\section{Options of High Altitude Community Forests in Sustainable Livelihoods \& Biodiversity Conservation}

Livelihoods of high altitude dwellers are diversified in nature. They are self-reliant in sustaining most part of their livelihoods. They mostly depend on forest for fulfilling their basic needs on vegetables, fruits, medicinal plants, organic manure, fodder, fuel wood, timber etc. High altitude 
community forest possesses a large range of pasture land which provides livestock for grazing as well as valuable NTFPs for collectors. It also provides shelter (hut/Goth) for the herders as well as livestock during the summer and rainy season. It is also a reservoir of important and commercially viable biological diversity which has a great potential for bio-prospecting. High altitude areas have over-stocked forests with a large amount of over-matured, dead, dying and diseased trees. These forests can fulfill a great portion of national demand of timber and fuel wood if they are properly and sustainably utilized. Majority of ethnic communities live in high altitude who possess a valuable indigenous knowledge, skill and technology (IKST) that can be documented and registered in a concerned authority and protect the intellectual property rights of the community and potential for economic benefits to the community.

High altitude areas have the mosaics of ethnic communities having new varieties of foods, pleasing environment etc. as well as attractive landscape composed of deep gorges, high water falls, highly capped mountains, seasonal snowfall, beautiful wild flora and fauna, clear sky and twinkling stars in the night, enjoying climate etc. make a high potential for ecotourism commonly called as culture tourism, village tourism etc. which helps in promotion of livelihoods assets.

\section{Conclusion}

Livelihoods of high altitude dwellers are complex in nature which is interlinked with forests, livestocks, and agriculture. Their livelihoods may become vulnerable if grazing of livestocks, construction of Goth and collection of NTFPs will be prohibited from the community forests. If the present trend of wildlife hunting is not controlled by high altitude community forest users group, wildlife population will be totally lost within a few decades. Commercially viable NTFP resources of high altitude are sharply declining from the forests as well as pasture land. Overstocked forests can be utilized in fulfillment of growing national demand of timber and fuelwood. Bursting epidemic diseases to the livestocks occur frequently in high altitude areas. Local people loose many livestocks without getting veterinary services from the concerned authority. High altitude communities have not yet been supported for upliftment of livelihoods of pro-poor users group. Governmental and non-governmental services are beyond the access of high altitude dwellers.

\section{Recommendation}

CFUG should take legislative action against wildlife hunting, and prohibit keeping the gun in Goth. Moreover, people's awareness program on biodiversity conservation especially on wildlife conservation should be launched. For effective biodiversity conservation in high altitude community forests, they should be classified into different environmental zones of the forests such as biodiversity conservation zones (core area of the forests), grazing and pasture zones (construction of Goth and cultivation of crops such as potato), religious and wetland zones (conservation of religious sites and wetlands), protected forest zones (areas environmentally sensitive, heavily land degradation etc.) and other environmental zones. CFUG should implement the programs according to the nature of environmental zones. CFUG should regulate the grazing and preparation of hut in the community forest as well as control the 
excess lopping of trees for fodder and cultivation of agricultural crops in the forest land. Rotational grazing system may support in protection of the regeneration, NTFPs and overall biodiversity.

Community forest users group (CFUG) should promote forest based enterprises such as Lokta handmade paper, Allo cloth, Nigalo and Bamboo crafts enterprises etc and sustainable harvesting of medicinal and aromatic plants. CFUG should devise a mechanism to utilize the over matured \& felled trees. It creates rural employment and subsequently reduces the poverty rate. Vocational trainings should be provided to the herders so as to protect the cattle from epidemic diseases. Government should modify the existing rules and regulations to allow construction of Goth and cultivation of crops such as potatoes.

\section{Acknowledgements}

We are highly acknowledged with Mr. Raj Dev Yadav, DFO, Pyuthan, Mr. Jhalak Poudel, District Programme coordinator, LFP, Pyuthan; Miss Naumati Budhamagar \& Srijana Thapa, LRP, LFP, Pyuthan and Mr. Nischal Hamal, Sociologist, High Altitude Forest Management Study Team .

\section{References:}

Acharya, D. (2003). Natural Resource Management in High Altitude Areas in Nepal: A Review and Synthesis of Information. Livelihoods \& Forestry Programme, Nepal.

Baral, N. (1996) . Ecologically and Economically Sustainable Forest Management of the High Altitude Forests of Nepal. A Master's Thesis in Environmental Management and Development. National Center for Development Studies, Research School of Asian and Pacific Studies, the Australian National University, Australia.

Baral , N. (2003) . Upper Slopes Community Based Resource Management: Working Strategy: APreliminary Report. Nepal Australia Resource Management and Livelihoods Project.

Jackson, J.M.C. Nurse and R.B. Chhetri (1993) High Altitude Forests in the Middle Hills of Nepal: Can they be managed as Community Forestry? Banko Janakari: A journal of Forestry Information for Nepal, 4(1): 20-23.

Messerchschmidt, D.A. and S. Rayamajhi (1996). Upper Slopes Forest Management in Kavre Palanchowk and Sindhu Palchowk Districts, Nepal. A Study in Forest Resource Conditions and the Potential for People's Participation. Final Report of the Upper Slopes Forest Management Consultancy, Nepal Australian Community Forestry Project, Kathmandu.

Metz, J.J. (1990). An Outline of the Patterns of Natural Vegetation Use in Upland Nepal. Mountain Research and Development 10(1): 7-15.

Pradhan,S.L. , Hitchock,D.K. and Miller,D.(2000b). Natural Resource Management in Relation to Livestock in the Upper Slope Areas : Sindhupalchowk district.Presented to the Fourth Animal Science Convention Organized by Nepal Animal Science Association, 29 November to 1 December, Kathmandu. 
Rai,N.k. and Thapa, M.B. (1993) . Indigenous Pasture Management System in High Altitude Nepal: A Review. Report Series No. 22, HMG Ministry of Agriculture / Winrock International.

Rawal, R.B. (1998). Challenges and Opportunities in Developing Community Based Forest Enterprises in the Higher Mountain of Nepal. Biodiversity Support Programme and New ERA Ltd.

Sedhain,D. (1993) . A study of the Transhumant System of Management of Sheep in Rasuwa and Nuwakot Districts. In : Tamang, D. ; Gill , G.J. and Thapa, G.B. (eds.) Indigenous Management of Natural Resources in Nepal, HMG Ministry of Agriculture / Winrock International, Kathmandu.

Shrestha, K. (2000). High Altitude Forest Management. In: Community Forestry in Nepal: Proceedings of the Workshop on Community Based Forest Resource Management, Godawari, Lalitpur. November 20-22, 2000. Joint Technical Review Committee.

Shrestha, L.P. (1998). High Altitude Pastoral System in Nepal. In: Proceeding of the Third meeting of Temperate Asian Pasture and Fodder Network (TAPAFON), 9-13 March, 1998, Pokhara, Nepal.

Shrestha,K.K. and Pariyar, D. (1998) . High Altitude Pastoral System Study of Sailung Rangeland. In : Proceeding of the Third meeting of Temperate Asian Pasture and Fodder Network (TAPAFON), 9-13 March, 1998 Pokhara, Nepal.

Subedi, R. (2003). LFP Strategy for NTFP Promotion: A Report of livelihoods and forestry programme. Livelihoods \& Forestry Programme, Baglung

Thakur, R.B. (2005). Resource Assessment \& Market Analysis of NTFPs of High Altitude Government Managed Forest for Enterprise Development: A Case Study from Bachchha ,Bhoksin \& Barachaur VDCs of Parbat District . Livelihoods \& Forestry Programme, Parbat.

Thakur, R.B. (2005). Strategic Management Plan of Non Timber Forest Products of High Altitude Government Managed Forests of Parbat District. Livelihoods \& Forestry Programme, Parbat.

Thakur, R.B. (2005).Assessment of NTFPs of High Altitude Government Managed Forest for Enterprise Development: A Case Study from Hosrandi and Uram Pokhara VDCs of Parbat district. Thesis, Institute of Forestry, Pokhara Campus, Pokhara, Tribhuvan University.

Thakur, R.B. (2006).Financial Analysis of Forest Based Enterprises and Their Contribution in Sustaining Livelihoods of Rural People: A Multiple Case Studies From Parbat District . Livelihoods \& Forestry Programme, Parbat. 
Thakur, R.B. (2008). Strategic Management Plan of High Altitude Government Forest of Ghamire Lek, Rolpa district. Livelihoods \& Forestry Programme, Mid-West Programme Co-ordination Office, Ghorahi, Dang.

Thakur, R.B. (2008). Strategic Management Plan of High Altitude Forests of Rukum District: A Case Study from Sepe Charpate Community Forest of Ransi VDC \& Government Managed Forests of Kol \& Kankri VDCs. Livelihoods \& Forestry Programme , MidWest Programme Co-ordination Office, Ghorahi, Dang .

Thakur, R.B. (2008). Strategic Innovations of Sustainable Livelihoods \& Biodiversity Conservation of High Altitude Forests of Pyuthan district: ACase Study from Syaulibang, Rajabara, Arkha \& Khung VDCs . Livelihoods \& Forestry Programme, Mid-West Programme Co-ordination Office, Ghorahi, Dang.

Yonzon, P. (1998). Biodiversity Conservation of Rangeland. In : Proceedings of the Third meeting of Temperate Asian Pasture and Fodder Network (TAPAFON), 9-13 March, 1998, Pokhara, Nepal.

"पर्यटन पूर्वाधारको विकास गरौं

प्रसिद्ध स्थल खप्तड क्षेत्र पर्यटन प्रर्वधन कार्यमा हामी सवै जुटौं”

\section{विजया दशमी तथा शुभ-दिपावली २०६६ को} पुनित उपलक्ष्यमा

समस्त पर्यटन व्यवसायी एवं शुभेच्छुक महानुभावहरुमा हार्दिक मंगलमय शुभ-कामना व्यक्त गर्दछौं।

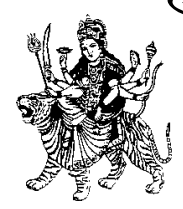

खप्तड क्षेत्र पर्यटन विकास सभिति परिवार खप्तड, नेपाल

फोन नं. ०९४-पू२०३७६ (डोटी), ०१-६९१६२६१ (काठमाण्डौ) सम्पर्क कार्यालय : ववरमहल, काठमाण्डौं 